Pamiętnik Literacki 2020, 2, s. 133-152

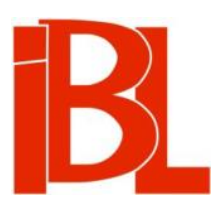

\title{
Uwagi o polskiej liryce psalmicznej drugiej połowy wieku XVI
}

Mirosława Hanusiewicz-Lavallee 
Pamiętnik Literacki CXI, 2020, z. 2, PL ISSN 0031-0514

DOI: $10.18318 / \mathrm{pl} .2020 .2 .10$

MIROSŁAWA HANUSIEWICZ-LAVALLEE Katolicki Uniwersytet Lubelski Jana Pawła II

\section{UWAGI O POLSKIEJ LIRYCE PSALMICZNEJ DRUGIEJ POLOWY WIEKU XVI}

Staropolska literatura psałterzowa od dawna przyciaga uwagę badaczy, zwykle w kontekstach problematyki kształtowania się stylu biblijnego w polszczyźnie czy funkcji Księgi Psalmów w kulturze literackiej i religijnej wspólnot chrześcijańskich dawnej Rzeczypospolitej. Studia te najczęściej skupiają się na opisie i analizie pełnych kolekcji psalmicznych w języku polskim, zarówno tych stanowiących składnik całościowych przekładów Biblii, jak i tych oferowanych czytelnikom (orantom) jako materiał osobistej modlitwy i medytacji bądź też jako kancjonał zawierający wierszowane psalmy $z$ melodiami ${ }^{1}$. Rzadziej jednak stawiany jest problem kształtowa-

1 Zob. np. A. Br ü ckn er, Psałterze polskie do połowy XVI wieku. Kraków 1902. - S. D o b r zy c ki, Psałterz Kochanowskiego: jego powstanie, źródła, wzory. Kraków 1910. - K. Gą si or ow ski: Ks. Jakub Wujek jako tłumacz „Psatterza Dawidowego”. Lublin 1952 (rozprawa doktorska, mps BKUL); Dwa Psałterze ks. Wujka. „Ruch Biblijny i Liturgiczny” 1959, nr 3. - S. Ro s p o n d, Język renesansu a średniowiecza na podstawie literatury psałterzowo-biblijnej. W zb.: Odrodzenie $w$ Polsce. Materiały sesji naukowej PAN, 25-30 października 1953 roku. T. 3, cz. 2. Red. M. R. May e n owa, Z. Klem e n s i ew i c z. Warszawa 1962. - M. Ko s s ow s ka, „Biblia” wjęzyku polskim. T. 1-2. Poznań 1968. - E. O s t r o w s ka, Walka o piękne słowo psałterzowe. „Psatterz” Kochanowskiego i „Psałterz” brzeski. W: Z dziejów języka polskiego i jego piękna. Studia i szkice. Kraków 1978. - S. U rb án c zy k, „Psałterz” w przekładzie Jakuba Lubelczyka i Jana Kochanowskiego. W zb.: Jan Kochanowski 1584-1984. Epoka, twórczość, recepcja. Red. J. Pelc, P. B u c hwald - Pelc owa, B. Otwin ows ka. T. 1. Lublin 1989. - K. Melle r: „Ducha zacnego doktora Pawła Milejewskiego, którym pałał i ty psalmy pisał..." - podsłuchanie. W zb.: Dwór majacy $w$ sobie osoby i mózgi rozmaite. Studia z dziejów literatury i kultury. Red. B. Si e n k i e w i c z, B. J u d k owiak. Poznań 1991; Jakuba Lubelczyka „Psałterz Dawida” z roku 1558. Studium filologiczne. Poznań 1992; wstęp w: J. K o c h a n o w s ki, Psałterz Dawidów. Oprac. K. M elle r. Kraków 1997; Psalm - kalwińska „pieśń nad pieśniami”. O kształtowaniu się ewangelickiej kultury literackiej i duchowej. Na przykładzie przekładów i parafraz „Liber Psalmorum” z XVI i XVII wieku. W zb.: Ewangelicyzm reformowany $w$ Pierwszej Rzeczypospolitej. Dialog z Europa i wybory aksjologiczne $w$ świetle literatury i piśmiennictwa XVI-XVII wieku. Red. nauk. D. Ch e m per ek. Warszawa 2015. - P. Bu chwald-Pelcowa, Nad psalmami i psałterzami polskimi XVI wieku. W zb.: Nurt religijny $w$ literaturze polskiego średniowiecza i renesansu. Red. S. Ni e z n a n ow ski, J. Pelc. Lublin 1994. - M. C y b u ls k i, Staropolskie przekłady „Psałterza”. Lódź 1996. - R. P i e t ki e w i c z: „Pismo Święte” $w$ języku polskim $w$ latach 1518-1638. Sytuacja wyznaniowa $w$ Polsce a rozwój edytorstwa biblijnego. Rozprawa doktorska. Wrocław 2003. Na stronie: http://digital.fides.org.pl/ Content/728/Pietkiewicz-Doktorat.pdf (data dostępu: 10 XI 2019); Biblia Polonorum. Historia „Biblii” w języku polskim. T. 1: Od poczatku do 1638 roku. Poznań 2016. - E. B u s z e w i c z, Jan Kochanowski: „Psałterz Dawidów”. W zb.: Lektury polonistyczne. Jan Kochanowski. Red. A. G o r zk o w s ki. Kraków 2001. - A. G o r z k o w s ki i, „Cóż się stanie, Panie, jeśli spytam?” Studia i szkice 
nia się w poezji staropolskiej form lirycznych, które przekodowują i aktualizują model biblijny w idiomie rodzimej tradycji. Wiersze te - nie będac przekładami - na różnych poziomach związków intertekstualnych do pieśni Dawidowych wszakże odsyłają, czasem zaś w tytule czy podtytule autorzy identyfikuja je jako „psalmy”. W niniejszym szkicu pisać o nich będę jako o liryce psalmicznej, przywołując na myśl przede wszystkim utwory, w których słowo biblijne podlega rekonfiguracji, by stać się budulcem oryginalnego monologu lirycznego, zindywidualizowanego lub też zaadaptowanego do określonej sytuacji (np. historycznej bądź osobistej). Choć uwagi dotyczące tego zjawiska będą miały w najlepszym razie charakter wstępny i wskażą jedynie na moment jego kształtowania się (odnosząc się zresztą do utworów powszechnie znanych i mających bogatą literatura przedmiotu), sądzę, że potrzeba podjęcia tej refleksji i przeprowadzenia pewnych rozróżnień wynika $z$ zasadniczej roli, jaką tak rozumiana „psalmodia” odegrała w formowaniu nowożytnej liryki religijnej w ogóle, odchodzącej od średniowiecznego schematu „Zwrotu i prośby”, a skierowanej raczej ku introspekcji i osobistemu dialogowi z Boskim Adresatem.

Nawet w charakterystycznej dla renesansu oraz baroku stabilnej, uporządkowanej taksonomii literackiej psalmy okazywały się pod względem formy gatunkowej kłopotliwe i nieoczywiste, głównie z powodu słabego rozumienia cech poezji hebrajskiej. Co do tego, że poezją były, nie żywiono jednak wątpliwości. Zapewniał o tym Filon z Aleksandrii ${ }^{2}$. Także Józef Flawiusz pisał o owych utworach jako o poetyckich, w dodatku złożonych w heksametrach, pentametrach i trymetrach; cokolwiek miały znaczyć te określenia w materii języka hebrajskiego, to niewątpliwie konotowały poetyckość psalmów. Podobnie ujmowali to Orygenes i Euzebiusz ${ }^{3}$. Od czasów św. Hieronima w świecie chrześcijańskim była ona faktem nie budzącym kontrowersji. W mającym formę listu do Wincentego i Galiena wstępie do Hieronimowego przekładu Kronik (Chronicon) Euzebiusza z Cezarei czytamy:

Cóż [...] jest bardziej muzycznego (łac. canorius) od Psałterza, który, na sposób naszego Flakka i Greka Pindara, a to pomyka jambem, a to dźwięczy strofą alcejska, a to wzbiera saficką lub rusza naprzód półstopą! Cóż piękniejszego od Księgi Powtórzonego Prawa i Kantyku Izajasza, cóż wznioślejszego od Salomona, cóż doskonalszego od Hioba! Wszystkie te księgi, jak pisali Józef i Orygenes, w oryginale płyną heksametrami i pentametrami ${ }^{4}$.

o myśli i tradycji biblijnej. Kraków 2012. - M. M. S z u r e k, Z dziejów polszczyzny biblijnej. „Biblia” Wujka (1599) a „Biblia” gdańska (1632). Kraków 2013.

2 Zob. J. L. Kugel, The Idea of Biblical Poetry: Parallelism and Its History. New Haven 1981, s. 162-163.

3 Zob. D. Broadribb, An Attempt to Delineate the Characteristic Structure of Classical (Biblical) Hebrew Poetry. Bakers Hill 1995, s. 29.

4 Hi e r o n y m u s, Praefatio in Eusebii Caesariensis „Chronicon” 3 (Patrologia Latina 27, 36-37). Cyt. za: B. D e gó r s k i, Wstęp św. Hieronima do jego przekładu „Kroniki” Euzebiusza z Cezarei. „Rocznik Teologii Katolickiej” 12 (2013), s. 149: „Denique quid "Psalterio" canorius, quod in morem nostri Flacci, et Graeci Pindari nunc iambo currit, nunc alcaico personat, nunc Sapfico tumet, nunc senipede ingreditur. Quid "Deuteronomii" et Esaiae "Cantico" pulchrius, quid Solomone gravius, quid per- 
Poczucie owej poetyckości umacniały próby parafraz, takie jak ta podjęta przez Paulina z Noli, który rzeczywiście zaaplikował klasyczne metra do swych trzech łacińskich przeróbek psalmów. Choć naśladowców przez długi czas nie było, to przecież w tradycji literackiej średniowiecza Dawid pozostawał archetypem poety sięgającego po najbardziej wzniosłą formę wypowiedzi, gdyż podejmującego dia$\log$ z samym Bogiem. W takiej roli pojawia się np. w Boskiej Komedii jako najwyższy śpiewak najwyższego Pana („sommo cantor del sommo ducè”, Par. 25, 72), ten, który śpiewa teodia i swą pieśnią wlewa nadzieję w serce florenckiego wygnańca, zarazem wytyczając jego drogę twórczą ${ }^{5}$. Dantejska nobilitacja Dawida-poety nie pozostanie bez znaczenia dla rozwoju poezji psalmicznej w renesansowej literaturze włoskiej ${ }^{6}$, która całkiem już bezpośrednio oddziaływać będzie na lirykę polską.

Kształtujący się u schyłku starożytności monastycyzm wpłynął na nadanie psalmom szczególnego statusu w modlitwie i liturgii chrześcijańskiej. Pawłowe wezwanie, sformułowane w Pierwszym Liście do Tesaloniczan $(5,17)$ „nieustannie się módlcie", traktowali świątobliwi ojcowie pustyni literalnie, a narzędziem owej ustawicznej modlitwy miało być właśnie codzienne śpiewanie całego Psałterza. Już u schyłku wieku IV ta praktyka okazała się inspirująca dla Kościoła, w kolejnych zaś stuleciach pobożność monastyczna zinterpretowana została jako domagający się naśladowania standard heroizmu duchowego ${ }^{7}$. Psalmodia stanowiła podstawę liturgii monastycznej, a że psalmów należało nauczyć się na pamięć, służyły one zwłaszcza niepiśmiennym kandydatom do życia klasztornego - również jako instrument nauki języka łacińskiego ${ }^{8}$.

Psalmy śpiewano, co podkreślało ich charakter pieśniowo-poetycki i odróżniało od lectio oraz modlitw. $Z$ drugiej jednak strony, mnisi dysponowali licznymi komentarzami do Księgi Psalmów, które odsłaniały przede wszystkim ich sens alegoryczny i moralny oraz ukazywały je jako teksty profetyczne, odnoszące się do Chrystusa i Jego Kościoła, domagające się skupionej medytacji. Począwszy od Tractatus in psalmos św. Hieronima, za którego pośrednictwem średniowieczny czytelnik poznawał także metodę egzegetyczną Orygenesa, przez Objaśnienia psalmów (Enarrationes in psalmos) św. Augustyna, dzieła Kasjodora, Grzegorza Wielkiego, Izydora z Sewilli, Bedy Czcigodnego, Gilberta z Poitiers, Honoriusza z Autun, Piotra Lombarda, Hugona de Sancto Caro, Ludolfa Saksończyka (by wspomnieć tylko najbardziej wpływowe teksty), komentarze „otwierały” lirykę Dawidową na

fectius Iob. Quae omnia hexametris et pentametris versibus, ut Iosephus et Origenes scribunt, apud suos composita decurrunt". Przekład na jezzyk polski - M. H.-L.

5 Zob. P. S. Hawkin s, The Psalms in Poetry. W zb.: The Oxford Handbook of the „Psalms”. Ed. W. P. Brown. Oxford 2014, s. 99-100.

6 Zob. E. Pi e t r o b a n, La penna interprete della cetra. I Salmi in volgare e la tradizione della poesia spirituale italiana nel Cinquecento. Tesi di dottorato. Padova 2015, s. 21 n. Na stronie: http://paduaresearch.cab.unipd.it/8028/ (data dostępu: 28 X 2019).

7 Zob. J. W. M c Kin n o n, „The Book of Psalms”, Monasticism, and the Western Liturgy. W zb.: The Place of the Psalms in the Intellectual Culture of the Middle Ages. Ed. N. V a n D e u s e n. Albany, N. Y., 1999, s. 49-50.

8 Zob. J. Dy er, The Singing of Psalms in the Early Medieval Office. „Speculum” 1989, nr 3 (July), s. 535-543. 
interpretacje odpowiednie dla chrześcijanina, a przy tym najbardziej osobiste. Ustalały też pewne zespoły tematyczno-gatunkowe, które miały odegrać ważną rolę w tradycji średniowiecznej i nowożytnej, np. Expositio Psalmorum Kasjodora definitywnie wyodrębniła grupę tzw. siedmiu psalmów pokutnych. Jeśli nawet komentarze pozostawały przedmiotem lektury stosunkowo nielicznych uczonych czytelników, to docierały do tych mniej wykształconych za pośrednictwem glos, którymi opatrywano średniowieczne psałterze, ale i charakterystycznych tituli psalmorum (istniało dla nich sześć serii tematycznych), wskazujących właściwy kierunek egzegezy ${ }^{9}$. W ten sposób psalmy, nie przestając być poezją w najgłębszym sensie tego słowa, stawały się jednak również źródłem modlitewno-medytacyjnym i w takiej właśnie roli polskie psałterze prozaiczne pojawiają się już w kulturze literackiej oraz religijnej dojrzałego średniowiecza, zachowując zresztą ową funkcję w okresach renesansu i baroku. Glosowane, opatrywane argumentami czy dodatkowymi modlitwami kolekcje, takie jak tzw. psałterz krakowski (wyd. 1: 1532), Żołtarz Dawidów (wyd. 1: 1539) Walentego Wróbla i Psałterz Dawidów (wyd. 1: ok. 1541-1546) przypisywany Mikołajowi Rejowi, osobno tłoczone psałterze: brzeski (1564), wyekscerpowany z Biblii Leopolity tzw. psałterz trydencki (1579), Psałterz Dawidów Jakuba Wujka (wyd. 1: 1594), gdański (1633), antytrynitarskie Psalmy Dawidowe na modlitwy chrześcijańskie przełożone (1587) Jakuba Milejewskiego czy wreszcie Paraphrasis na „Psałterz Dawidów” (1688) Wojciecha Tylkowskiego - mimo różnic konfesyjnych $\mathrm{w}$ istocie służyły podobnym celom, były modlitewnikami odpowiednimi dla pobożności prywatnej, w niektórych wypadkach zbliżając się formą do brewiarza (dla świeckich, ale też, w wersjach katolickich, dla panien zakonnych).

Fenomen psałterzy wierszowanych, które pojawiły się w literaturach wernakularnych w wieku XVI i niemal bezwyjątkowo związane były z pobożnością protestancką, również wymaga - w moim przekonaniu - odróżnienia od zjawiska liryki psalmicznej. U progu reformacji Marcin Luter nie tylko zachęcał współwyznawców do tworzenia metrycznych parafraz psalmów, ale i sam był autorem ośmiu (Ps 11-14, 46, 67, 124, 130), które opublikowane zostały w kancjonałach z lat 1524-1531, począwszy od pierwszego w ogóle śpiewnika protestanckiego, czyli Etlich Christlich lieder (1524), a zwłaszcza Erfurt Enchridion (1524). Psalmy wierszowane w językach narodowych, opatrzone muzyka, zmieniały się w hymny kościelne (jak np. słynny „hymn reformacji”, czyli Ein feste Burg ist unser Gott, będący parafrazą Psalmu 46) i służyły partycypacji wiernych w życiu religijnym kongregacji ${ }^{10}$. Za św. Augustynem, który w Objaśnieniach psalmów widział synopsis całego Pisma Św. i w ogóle teologii, Luter w przedmowie do drugiego wydania swego tłumaczenia Psałterza

9 Zob. ibidem, s. 536-538. Na temat tituli psalmorum zob. przede wszystkim - P. Salm on, Les "Tituli psalmorum” des manuscrits latins. Paris 1959.

10 Zob. E. H. La u er, Luther's Translation of the Psalms in 1523-24. „The Journal of English and Germanic Philology” 1915, nr 1, s. 29. - L. P. S pelman, Luther and the Arts. „The Journal of Aesthetics and Art Criticism" 1951, nr 2, s. 167-168. 
(1528) nazwał Księgę Psalmów „mała Biblia”"11. To sformułowanie, wyrastające $z$ przekonania o chrystologicznym i profetycznym charakterze pieśni Dawidowych, będzie powtarzane i uzasadniać będzie kolejne przekłady: „Psalmy bowiem są niejaką Pisma Św[iętego] summą, łaski Bożej wizerunkiem dostatecznym, całego człowieka wyrażeniem i, jako starzy mawiali, mała Biblija" - czytamy w skierowanej do „prawowiernego czytelnika” przedmowie do Psalmów Dawidowych z hymnami [...] Macieja Rybińskiego ${ }^{12}$. W tym skądinąd bardzo interesującym tekście pożytki płynące $z$ przewierszowywania Psałterza objaśniono następująco:

Psałterz Dawidów, iż jeszcze w kancyjonałach naszych cale nie był wydany, słusznie, ponieważ jest Słowem Bożym i zawsze w Kościele powszechnym tak czytając, jako i śpiwając używano go (bo jako Basilius mówi: psalmy ludzie w domu śpiewają, w drodze mówią i na polu z sobą noszą), ma mieć przodek i do śpiewania psalmów zrozumiałym językiem młódź z wielką pilnością ma być wprawowana. Gdyż i rzecz sama, którą w sobie psalmy mają, rychlej się, gdy wierszem podana bywa, w pamięć wpoi i czasu potrzeby pożytek uczyni ${ }^{13}$.

Uwagi te sformułowane zostały w kontekście wykładu dotyczącego śpiewu w kongregacji. Uprzywilejowana pozycja psalmów wynika tu wprost $z$ faktu, iż sa tekstami biblijnymi, kształt metryczny zaś i „zrozumiały język” służyć winny celom mnemotechnicznym oraz katechetycznym. I choć poetyckiego charakteru pieśni Dawidowych bynajmniej nikt nie kwestionuje, to wiersz w przekładzie ma po prostu przeznaczenie użytkowe. Co więcej, walor estetyczny bywa poniekąd dezawuowany, a przynajmniej uznawany za drugorzędny. Takie czy inne przekłady zaleca przede wszystkim to, że są „do sznuru Pisma Świętego” stosowane, wiernych zaś przestrzega się, aby „się nie tak na not wdzięczności abo rytmów składności, abo nawet na ozdobnej polszczyźnie, jako na prostocie a szczyrości serdecznej prawdziwe nabożeństwo [...] sadziło" ${ }^{14}$. Podobne zastrzeżenia czynił wcześniej Jakub Lubelczyk:

Bo jeślibyś [,krześcijański człowieku a bracie”] tak u siebie rozumieć chciał, iż to sa rytmy abo jakie rzeczy dworne - czego Kościół święty nie potrzebuje; bo on jedno tego chce, aby każdy w prostości ducha chwalił Pana Boga - aleć mnie sie tak zda, iż mie tu nie będziesz z czego winić miał, a to z tej przyczyny, iż sie tu i wierszom, i tekstowi folgować musiało ${ }^{15}$.

Polskie psalmy metryczne pojawiły się zatem we wspólnotach protestanckich Rzeczypospolitej jako fenomen estetycznie neutralny, sprzymierzeniec ze wszech miar rekomendowanej prostoty i skrypturalizmu. Pojawiły się zaś z tych samych powodów i z podobną dynamika, co w innych krajach objętych reformacja - poczynając od pojedynczych utworów autorstwa Jana Seklucjana, Bernarda Wojewódki, Andrzeja Trzecieskiego, Mikołaja Reja, zapewne Cypriana Bazylika, publikowanych

W. M. Mars h, Martin Luther on Reading the „Bible” as Christian Scripture. The Messiah in Luther's Biblical Hermeneutic and Theology. Foreword R. Kolb. Eugene 2017, s. 60.

[A. H ü n e f eld], Do prawowiernego czytelnika przedmowa. W: Psalmy Dawidowe z hymnami [...]. Przeł. M. Rybiński, J. Ge mbicki. Gdańsk 1619, k. )?( ijjr.

Ibidem.

Ibidem., k. [ )?( VI]r.

J. L u b e l c zy k, Ku każdemu krześcijańskiemu człowieku a bratu w Panu Krystusie krótka przedmowa. W: Psałterz i kancjonat z melodiami drukowany w 1558 roku. Wyd. J. S. Gruch ał a, P. Poźniak. Kraków 2010, s. 69. W cytatach z tego wydania pomijam oznaczenia pochylenia samogłosek. 
w latach 1546-1565, po pełne kolekcje, takie jak właśnie Psałterz Dawida (1558) Jakuba Lubelczyka czy Psalmy Dawidowe (1605) Rybińskiego ${ }^{16}$. Ich kształt wierszowy nie był sygnałem poetyckości, lecz służył mnemotechnice i samej melodii, tak by akt śpiewania wspierał memuaryzację Psałterza uważanego za sumariusz Biblii i za modlitewnik przewidziany na wszystkie sytuacje życiowe.

Zaznaczyć także trzeba, iż w staropolskiej protestanckiej kulturze religijnej psalm funkcjonuje głównie jako modlitwa całej kongregacji i element pobożności wspólnotowej. Tak więc już Seklucjan usiłował dostosowywać zarówno swe pieśni kancjonałowe, jak i pojedyncze psalmy do kształtu wierszowego oraz melodii niemieckich, jako pierwszy też tłumacząc m.in. „hymn reformacji”, czyli sławną Lutrową wersję Psalmu 46: Ein feste Burg ist unser Gott (inc. „Przednie mocny grunt jest Pan Bóg nasz”). Jakub Lubelczyk, „zalecając swe służby” Łukaszowi Górce, stwierdza, że „wyznawanie [...] w psalmiech możności Pańskiej to jest zawżdy nawdzięczniejsza a naprzyjemniejsza chwała w zebraniu Kościoła świętego"17, Adrzej Hunefeldt zaś w przedmowie do edycji dzieła Rybińskiego z 1616 roku pisze:

psalmy wszystkie proroka ś[więtego] Dawida podług melodyj francuskich na polski język przełożył [Rybiński] [...], aby w Zborze Pańskim, ile możno, równość była, a Pan Bóg wszechmogący od zebrania swego jednomyślnie i jednym głosem był pochwalon i uczczon ${ }^{18}$.

Mimo uznania, $\mathrm{z}$ jakim przyjęto w polskich wspólnotach reformowanych Psatterz Dawidów Kochanowskiego, dzieło nie spełniało tego właśnie warunku, gdyż niedostosowane do melodii Psałterza genewskiego (C. Marota - Th. de Bèze'a, 1587) - nie zapewniało owej ,jednomyślności” w głoszeniu chwały Bożej. Psałterz Rybińskiego okazywał się wolny od tego niedostatku i, co więcej, był pomyślany jako instrument zgody między zwaśnionymi kongregacjami a Kościołami protestanckimi, tekst ujednoliconej obrzędowości ${ }^{19}$. Choć wydaje się oczywiste, że jako teksty meliczne i metryczne psałterze te również dokonują swoistego „przekodowania" i transpozycji słowa biblijnego do materii rodzimej, polskiej tradycji literackiej, a nawet poetyckiej, to przecież szczególny respekt dla tekstu natchnionego i troska o to, by niczego $\mathrm{z}$ niego nie uronić ani też go nie zniekształcić, kieruje je w stronę „poetyki negatywnej” (by użyć formuły zaproponowanej niegdyś przez Alinę Nowic-

Zob. Melle r, Jakuba Lubelczyka „Psałterz Dawida” z roku 1558. - R. Pi et ki ewicz: Edycje pojedynczych psalmów i ich zbiorów renesansowej Rzeczypospolitej. W zb.: Patrzmy na Jezusa, który nam $w$ wierze przewodzi. Księga pamiatkowa dla Księdza Profesora Jana Łacha $w 85$ rocznice urodzin. Red. W. Ch r o s t ow ski, B. Strzałk ow s ka. Warszawa 2012; Biblia Polonorum, s. 254-262, 296-309, 322-330. Choć najstarsza zachowana edycja Psalmów Dawidowych Rybińskiego to właśnie 1605 r. (w Rakowie, w oficynie S. Sternackiego), niektórzy badacze przypuszczają, że istniały wcześniejsze. Zob. też J. Z d a n ow i c z, „Psałterz” Rybińskiego (wraz z wykazem polskich kancjonałów i psałterzy z XVI w.). „Muzyka. Kwartalnik Instytutu Sztuki Polskiej PAN” 1957, nr 3. - M. A. K or z o, „Psalmy Dawidowe” (Gdańsk 1616). Przyczynek do recepcji „Katechizmu Heidelberskiego” w Polsce. „Biblioteka” 2013, t. 17, s. 57-58.

17 J. Lu be l c zy k, Jaśnie wielmożnemu Panu, Panu Łukaszowi Górce [...] mały i mało znajomy stużebnik służby swoje zaleca i ofiaruje. W: Psatterz i kancjonał z melodiami drukowany w 1558, s. 65.

18 J. H un efeld t, Zacnie urodzonemu Jego Mości Panu, Panu Hernestowi Krokowskiemu [...]. W: M. Rybiń s ki, „Psalmy Dawidowe” [...] na melodyje Psalmów francuskich urobione. Gdańsk 1616, s. 7.

19 Zob. Pi etki ew i c z, „Pismo Święte” w języku polskim $w$ latach 1518-1638, s. 179. 
ką-Jeżową), ogranicza w istocie ich „literackość” ${ }^{20}$, co bynajmniej nie wyklucza leksykalnej redundancji.

Czynnikiem zmiany okaże się przede wszystkim oddziaływanie dwóch nurtów europejskiej poezji renesansowej - horacjanizmu i petrarkizmu duchownego.

Horacjanizm inspirował intensywny rozwój łacińskiej parafrazy psalmicznej, która już od lat trzydziestych XVI wieku poczęła się stabilizować - co zauważył Ian McFarlane - jako swoisty gatunek, by w ostatnich dekadach stulecia wchodzić nawet $\mathrm{w}$ fazę schyłkową ${ }^{21}$. W najświetniejszych (i wcześniejszych) realizacjach gatunku, takich jak Psalmorum Davidis paraphrasis poetica George'a Buchanana, kryło się jednak ziarno form o znacznie większym potencjale rozwoju. Psalmy, pojęte nie jako tekst medytacyjny, ale par excellence poetycki (a moda na metryczne parafrazy łacińskie poetyckość tę dobitnie eksponowała), okazywały się zaskakująco nowym i świeżym wzorcem liryki religijnej. Średniowieczny schemat modlitewnej poezji „Zwrotu i prośby” odsłaniał w ich kontekście swe ubóstwo i niemożność wyrażenia pełnej skali doświadczeń duchowych. Osiagnięcia humanistycznej filologii biblijnej podważyły autorytatywny charakter Wulgaty, odpowiedzialność za interpretację Pisma składając w dużej mierze na samego czytelnika ${ }^{22}$. Żywioł subiektywności naznaczył lekcję biblijną - także lekcję Księgi Psalmów - i w konsekwencji doszedł do głosu również w inspirowanej Biblia poezji lirycznej. Psałterz, zwłaszcza ten już zinterpretowany przez wybitnych parafrazatorów, takich jak Buchanan, jawił się jako thesaurus motywów, obrazów, stylów liryki indywidualnej, niemal prywatnej, archetypicznie odnoszącej się do wszystkich właściwie doświadczeń ludzkich. Pojęty jako rodzaj kodu, mógł podlegać aktualizującej rekonfiguracji ${ }^{23}$.

To właśnie owa rekonfiguracja, potraktowanie psalmu biblijnego jako modelu sytuacji lirycznej, biblijnej materii tekstowej zaś - jako elementu tworzywa nowego utworu, wydaje się kategorią kluczową. Tak rozumiany psalm przestaje być parafrazą, a tym bardziej przekładem, okazuje się natomiast pojemną (choć nieostrą) formą quasi-genologiczna, która stanie się nader produktywna w dalszym rozwoju liryki religijnej, współcześnie zaś - nawet świeckiej. Nie ma ona większych lub zgoła żadnych (co warto podkreślić) strukturalnych odniesień do psalmu hebrajskiego, który bynajmniej nie spełnia wobec niej funkcji „oryginału”, nie odgrywaja w niej znaczacej roli znamienne dla niego elementy, takie jak paralelizmy czy repetycje, kształtuje się raczej jako efekt aktualizacji lirycznej jakiegoś łacińskiego

A. Nowi cka-J eżowa, Pieśni czasu śmierci. Studium z historii duchowości XVI-XVIII wieku. Lublin 1992, s. 173-185. Zob. też K. M ell e r, „Noc przeszła, a dzień się przybliżyt”. Studia o polskim piśmiennictwie reformacyjnym XVI wieku. Poznań 2004, s. 219-222.

21 I. D. M c F arla ne, Buchanan. London 1981, s. 248.

22 Zob. np. B. Ki e fer Lew a ls ki, Protestant Poetics and the Seventeenth-Century Religious Lyric. Princeton, N. Y., 1979, s. 31-32. - H. H a m l in, Psalm Culture and Early Modern English Literature. Cambridge - New York 2004, s. 1.

23 Zob. R. Gree n, George Buchanan's Psalm Paraphrases in a European Context. W zb.: Scotland in Europe. Ed. T. H u b b ard, R. D. S. J a ck. Amsterdam - New York 2006, s. 27. 
albo wernakularnego przekładu bądź parafrazy psalmu, czasem wspartych lektura komentarza, i $z$ nich $w$ istocie wyrasta ${ }^{24}$.

Zarówno wątki starożytnej oraz średniowiecznej tradycji nie podzielonego jeszcze Kościoła łacińskiego, dziedzictwo modlitwy medytacyjnej, jak i wątki żywe $\mathrm{w}$ teologii reformowanej współpracowały w uzasadnieniu psalmu jako otwartej na rekonfiguracje, kontaminacje i aktualizacje formy lirycznej ${ }^{25}$. Formy w istocie nowożytnej, choć kształtującej się w relacji, często intertekstualnej, do biblijnego pierwowzoru. Liryka psalmiczna zakładała „napisanie go na nowo”; jeśli taki „psalm” był przekładem, to w znaczeniu uformowania nowego podmiotu w biblijnej sytuacji lirycznej bądź odwrotnie. Nawiązania intertekstualne pełnią funkcję tropu kierującego odbiorcę ku archetypowi pieśni Dawida, a sam charakter wierszowy ma być transpozycją oryginalnej poetyckości, wyrażonej w innym idiomie literackim. Tak rozumiana liryka psalmiczna kształtuje się w łonie humanizmu chrześcijańskiego, który nie podległ jeszcze radykalnej konfesjonalizacji, w kontekście parafrazy metrycznej, $z$ która jednak nie jest tożsama. $Z$ tego względu jej źródeł bez wątpienia należy upatrywać (w perspektywie europejskiej) w sławnym dziele Buchanana, w perspektywie staropolskiej zaś - w Psałterzu Dawidowym Kochanowskiego.

Niezależnie od nie pozbawionego pewnych ambiwalencji stosunku mistrza z Czarnolasu do reformacji, jego „Psałterza pięć ksiazżeczek” (wiersz dedykacyjny Jego Miłości [...] Księdzu Piotrowi Myszkowskiemu, z łaski Bożej biskupowi krakowskiemu etc., w. $15^{26}$ ) niemal ostentacyjnie wpisuje się w odmienne rejestry twórcze niż te, w których wybrzmiał już głos protestanckich poprzedników ${ }^{27}$. Skała naj-

24 W tym kontekście warto jednak zauważyć, że Ku gel (op. cit.) w swej znanej książce poświęconej paralelizmom biblijnym zakwestionował powszechnie akceptowane przekonanie, jakoby stanowiły one wyróżnik części poetyckich i były hebrajskim ekwiwalentem wierszowego metrum; udowodnił, że paralelizmy są również niezbywalna cechą wielu innych fragmentów Biblii, które badacze od wieków zgodnie uznają za prozaiczne. Argumentując przeciwko samej idei poezji biblijnej, uczony uważał wszkaże, iż niektóre partie bądź księgi Pisma wykazują się większą intensywnością określonych struktur fonetycznych i składniowych. Krytycy stanowiska Kugela podkreślali, że - dyskwalifikując pojęcie poezji biblijnej - niesłusznie zakładał on, iż powinna ona być, jak w kulturze Zachodu, swoiście metryczna. Zob. np. F. Landy, Poetics and Parallelism: Some Comments on James Kugel's „The Idea of Biblical Poetry”. „Journal for the Study of the Old Testament” 1984, z. 28 (February). - R. Ra p h a e 1, That's No Literature, That's My Bible: On James Kugel's „Objections to the Idea of Biblical Poetry”. Jw., t. 27 (2002), z. 1 (September).

25 Zob. często cytowane słowa: „Librum hunc non abs re vocare soleo ["anatomia"] omnium animae partium: quando nullum in se affectum quisquam reperiet, cuius in hoc speculo non reluceat imago [Księgę tę nie bez powodu zwykłem nazywać anatomią wszystkich części duszy, nie ma bowiem uczucia, którego bylibyśmy świadomi, a które nie byłoby tu widoczne jak w zwierciadle]” (I. C a lvi n u s, „Librum Psalmorum” commentarius. Ed. A. Tholu c k. Cz. 1. Berolini 1836, s. VI). Uwaga ta eksponuje zarówno introspektywny wymiar poezji Dawidowej, jak i preferowany przez egzegetę egzystencjalny model jej lektury.

26 Wszystkie cytaty z Psałterza Dawidowego podaję według edycji: J. Ko chanowski, Dzieła wszystkie. Wyd. Sejmowe. T. 1: cz. 1-5. Oprac. J. W o r o n c za k. Wrocław 1982-1990. BPP, B26. W cytatach pomijam oznaczenia pochylenia samogłosek.

27 Gruntowny przegląd literatury przedmiotu dotyczącej problemów tożsamości konfesyjnej mistrza z Czarnolasu daje niedawne studium A. N ow i c k i e j - J e ż o w e j zatytułowane Jan Kochanowski wobec protestantyzmu (w zb.: Ewangelicyzm reformowany $w$ Pierwszej Rzeczypospolitej. Dialog z Europa i wybory aksjologiczne $w$ świetle literatury i piśmiennictwa XVI-XVII wieku. Red. nauk.

D. C h e mp e r e k. Warszawa 2015). Zob. też notę bibliograficzną (ibidem, s. 270-274). 
wznioślejszej spośród parnaskich muz pozostała przecież nietknięta znakiem „polskiej stopy” (w. 12), mimo trudu Lubelczyka, Reja, Trzecieskiego i innych. Choć przed uwodzicielskim urokiem, jaki roztacza Poetica (by przypomnieć sławny fragment Listu do Stanisława Fogelwedera), miała strzec poetę uzbrojona w gwoździe i spiże Necessitas, to przecież trudno tę horacjańską alegorię uznać po prostu za rygor skrypturalnej wierności, owego „sznuru Pisma Świętego”, który moderował prace autorów zborowych. W wierszu dedykacyjnym do Myszkowskiego mowa wyraźnie o emulacyjnym starciu „Z poety co znakomitszemi” (w. 10), a formuła ta kieruje raczej w stronę dobrze już wówczas rozwiniętego w Europie nurtu humanistycznych metrycznych parafraz łacińskich, eksponujących właśnie poetyckie i „klasyczne” walory pieśni Dawidowych ${ }^{28}$.

Nurt ten, zrodzony w łonie humanizmu chrześcijańskiego, konfrontował z notorycznym problemem taksonomii poezji biblijnej. Nie można jej było oprzeć na modelach klasycznych, które jednym z głównych kryteriów czyniły przecież metrum, a zastosowanie kryterium tematycznego wskazywało raczej na wielogatunkowość Księgi Psalmów ${ }^{29}$. Moda na tworzenie metrycznych łacińskich parafraz psalmicznych łączyła się u większości twórców z przekonaniem, że w księdze biblijnej odnajdują rozmaite rodzaje ód, co wymaga właśnie zróżnicowania metrum. Tak widział to Jean Gagnay, poprzednik i po części inspirator sławnego przedsięwzięcia $\mathrm{Bu}-$ chanana, które wywarło przemożny wpływ na Kochanowskiego, tak widział to również sam Buchanan. W przedmowie do swych Psalmi Davidici septuaginta quinque in lyricos versus, servata ecclesiasticae versionis veritate et Hebraeorum varietate (1547) Gagnay krytykował tych parafrazatorów (a należał do nich, oczywiście, Eoban Hessus), którzy przewierszowywali psalmy, posługując się jedynie dystychem elegijnym - dawało to, w jego przekonaniu, efekt żałobny i nie wyrażało zróżnicowania tematycznego oraz gatunkowego, choć, $z$ drugiej strony, występowanie elegii w Księdze Psalmów było oczywiste ${ }^{30}$. Zastrzeżenia Kochanowskiego względem parafrazy Hessusa, przedstawione w znanym fragmencie listu do Fogelwedera, zapewne również dotyczyły tego jej aspektu, choć pamiętać trzeba także, iż w perspektywie wyznaczonej przez luteranizm oba światy wartości, klasyczny i judeochrześcijański, okazywały się szczególnie trudne do pogodzenia, a przestrzeń negocjacji - bardzo wąska $^{31}$. Parafrazy Hessusa wpisywały się więc nie tyle w nurt emulacji poetyckiej (Kochanowskiemu przecież najbliższej), ile raczej dydaktyczno-katechetycznych ćwiczeń, zalecanych przez Philippa Melanchthona ${ }^{32}$.

Przedmowa Gagnaya zawierała także jego rozważania na temat sensu parafrazy jako takiej, którą rozumiał on jednak jako procedurę objaśniająca i interpretacyjna, bliską komentarzowi, nie zaś, w gruncie rzeczy, emulacyjną ${ }^{33}$. Bez wątpienia inaczej, mimo pewnych zewnętrznych podobieństw do przedsięwzięcia Gagnaya,

Zob. I. D. M c F a r la ne, Renaissance Latin Poetry. Manchester 1980, s. 94.

Zob. M c F arla ne, Buchanan, s. 249.

Zob. G. P. N o r t o n, The Ideology and Language of Translation in Renaissance France and Their Humanist Antecedents. Genève 1984, s. 164. 
który był jego paryskim gospodarzem i przyjacielem, pojmował swoje zadanie twórcze Buchanan w arcydzielnej Psalmorum Davidis paraphrasis, inspirującej dziesiątki naśladowców do emulacji przede wszystkim w zakresie polimetrii całego zbioru. O tych pracowitych poetach, którzy już w samych tytułach swych łacińskich, $\mathrm{w}$ istocie manierystycznych psałterzy z przełomu XVI i XVII wieku skwapliwie informowali czytelników, iż ich parafrazy wykorzystują kilkadziesiąt czy nawet sto miar wierszowych (wobec trzydziestu użytych przez samego Buchanana), w większości dziś nie pamiętamy ${ }^{34}$. Znamienne, że choć - jak wiemy skądinąd - Psalmorum Davidis paraphrasis szkockiego poety należała do najważniejszych dzieł inspirujących Psałterz Dawidów Kochanowskiego, to w jedynym jego utworze, w którym Buchanan w ogóle zostaje wspomniany, czyli w Foricoenium 68: Ad Buchananum, pojawia się ów z lekka ironiczny ton, gdy mowa o imitatorach, którzy „vatum nomen habere student [zabiegają o to, by zdobyć miano wieszcza]", i nie bez wysiłku próbują „wiązać” (aptare) struny łacińskiej liry do hebrajskich pieśni ${ }^{35}$.

O horacjanizmie Psatterza Dawidowego napisano już wiele i nie ma potrzeby, by powtarzać tu wcześniejsze ustalenia badaczy, wskazujących na inspirowaną poezją Wenuzyjczyka niezwykła varietas metryczną i stroficzną zbioru, bogactwo synonimiki i epitetów, wpływy ideowe, na bezpośrednie inkrustacje leksykalne, lecz również na horacjanizm „drugiego stopnia”, pośredni, wynikający z emulacji z łacińskimi twórcami, którzy jak Buchanan, ale przed nim także Marcantonio Flaminio usiłowali „przepisać” pieśni Dawidowe, nadając im cechy refleksyjnych ód i zakorzeniając je w estetyce oraz przestrzeni poetyckiej Pieśni (Carmina) ${ }^{36}$. Warto tu jednak podkreślić fakt, że już praktyki imitacyjne Kochanowskiego w odniesieniu do ód Horacego, obserwowane przez badaczy czy to w Lyricorum libellus, czy w Pieśniach, charakteryzowały się wielką swobodą nawiązań do tekstu będącego przedmiotem naśladowania, tak że z materii Horacjańskiej mistrz czarnoleski tworzył nowe w istocie struktury poetyckie - ody rzymskiego liryka stawały się prototekstem, nie zaś podstawą przekładu bądź nawet parafrazy ${ }^{37}$. Kochanowski, sugeruje Elwira Buszewicz, zdaje się postępować zgodnie $z$ zaleceniami imitacyjnymi, które formułował Pico della Mirandola, by - czerpiąc z wielu źródeł - kształtować tekst

Zob. A. Modlińska - Pi e k a rz, Votum Davidicum. Poetyckie parafrazy psalmów w języku tacińskim $w$ XVI i XVII wieku. Lublin 2009, s. 78.

I. C o c h a n ovi u s, Foricoenium 68: Ad Buchananum. W: Elegiarum libri IV. Eiusdem Foricoenia, sive Epigrammatum libellus. Cracoviae 1584, s. 152-153. Zob. też tłumaczenie na język polski: J. Ko c h a n ow s ki, Z łacińska śpiewa Stowian Muza. Przeł. L. St aff. Warszawa 1986, s. 172. Zob. S. D o b r zy c k i, „Psałterz” Kochanowskiego. Jego powstanie, źródła, wzory. Kraków 1910. W. W e in t r a u b: Rzecz czarnoleska. Kraków 1977; O poezji religijnej Jana Kochanowskiego. W: Nowe studia o Janie Kochanowskim. Posł. T. Ulewicz. Kraków 1991. - Meller, wstęp. J. Pelc, Kochanowski. Szczyt renesansu $w$ literaturze polskiej. Warszawa 2001, s. 481-524. E. B u s ze w i cz: Jan Kochanowski: „Psałterz Dawidów”; Buchanan in Poland: Facts, Questions, and Paradoxes. W zb.: Acta Conventus Neo-Latini Bonnensis. Proceedings of the Twelfth International Congress of Neo-Latin Studies. Bonn 3-9 August 2003. Gen. ed. R. Schn u r. Ed. P. Gala nd - Hally n [i in.]. Tempe, Ariz., 2006.

Zob. Z. Gło mbiows ka, Łacińska i polska muza Jana Kochanowskiego. Warszawa 1988. E. B u s z e w i c z, Imitacja horacjańska $w$ tacińskiej twórczości Jana Kochanowskiego. „Terminus” 2014, z. 2, s. 165. 
nowy $^{38}$. Lecz właśnie ta emulacyjna swoboda, szczepiona na gruncie renesansowej liryki horacjańskiej, w konfrontacji z językową materią psalmu również przeobraża go w proto- czy może nawet architekst, a granica między jednym a drugim okazuje się nader płynna. Jak czytamy u Kochanowskiego w Psalmie 29:

\author{
Nieście chwałę, mocarze, Panu mocniejszemu, \\ Nieście chwałę, królowie, królowi więtszemu, \\ Jego ze wszech naświętsze imię wyznawajcie, \\ Jemu w kościele świętym Jego się kłaniajcie! [w. 1-4]
}

Psalm ten, uchodzacy za jeden $z$ najsilniej inspirowanych wersją Buchanana ${ }^{39}$, bardzo wyraźnie ujawnia niezależność lirycznego głosu czarnoleskiego poety. Oto $\mathrm{np}$. w zacytowanym fragmencie szkocki humanista zamiast prostego paralelizmu wersetów tekstu biblijnego zaproponował rozwinięty polisyndeton:
Seu dives auro es, sive opibus potens,
Seu marte parta clarus adorea,
Agnosce numen gratus, et huc refer
Guaecunque laetum ducis ad exitum.
Huic pange laudes et prece supplice
Rerum parentem concilia, et Dei
Nutu regentis stelliferam domum
Dignare iustis nomen honoribus ${ }^{40}$.

[Czy jesteś zasobny w złoto, czy opływasz w bogactwa, czy zdobi Cię Marsowa sława, z wdzięcznością uznaj Boga i przypisz Mu to, cokolwiek posiadasz u radosnego kresu. Jemu oddaj chwałę i proś o łaskę Ojca wszechrzeczy w pokornej modlitwie, i uczcij należycie imię Boga, który skinieniem włada gwiezdnym pałacem.]

Kochanowski na pozór więc bliższy się wydaje zwięzłości oryginału, co zresztą podkreślano w dotychczasowych analizach i interpretacjach ${ }^{41}$. Buchananowi zawdzięcza w tym miejscu chyba jedynie samą ideę bogaczy i mężnych wodzów skłaniających się przed majestatem Bożym. Z drugiej wszakże strony, polski poeta wprowadza elementy zupełnie nowe - opozycje mocy (potęgi) ludzkiej i Bożej oraz

B us ze wi c z, Imitacja horacjańska $w$ tacińskiej twórczości Jana Kochanowskiego, s. 155, przypis 16.

39 Zob. A. Sienicki, Stosunek „Psałterza” przekładania Jana Kochanowskiego do „Paraphrasis Psalmorum” Jerzego Buchanana. „Sprawozdanie Dyrekcji C. K. Gimnazjum Arcyksiężnej Elżbiety w Samborze" 1893, s. 59.

40 G. Buchanani Scoti Psalmus XXIX. W: Paraphrasis „Psalmorum” Davidis poetica. Glasuae 1750, s. 55, w. 1-8.

41 Zob. łacińską translację S. P a g n i n i e g o („Liber Psalmorum” Davidis tralatio duplex [...]. 〈Genève〉 1556, s. 88, w. 1-2): „Date Iehovae, filii fortium, afferte Iehovae gloriam et fortitudinem. / Date Iehovae gloriam nominis eius, incurvate vos Iehovae in gloria sanctitatis [Ofiarujcie Jahwe, synowie mężnych, przynieście Jahwe chwałę i moc. / Ofiarujcie Jahwe chwałę Jego imienia, pokłońcie się Jahwe w chwale świętościl”, również wykorzystywaną przez autora polskiego. Tu i w kolejnych przypisach, w których przywoływane są wersety psalmiczne w różnych przekładach łacińskich, w nawiasach kwadratowych proponuję własne tłumaczenie filologiczne.

Zob. też uwagi W e in tra u b a (O poezji religijnej Jana Kochanowskiego, s. 90-91) oraz M. Han u s i e w i c z - La va ll e e (W stronę Albionu. Studia z dziejów polsko-brytyjskich zwiazków literackich $w$ dobie wczesnonowożytnej. Lublin 2017, s. 143-151). 
ziemskiego i niebieskiego królowania. Maja one głębokie implikacje biblijne i nawiązują do idei Mesjasza jako króla królów (zob. Dn 7; Ap 19, 16), subtelnie otwierając perspektywę chrystologiczną i apokaliptyczną (być może, nie docenioną w dotychczasowych interpretacjach Psałterza Dawidowego). Jak widać, Kochanowski rezygnuje $z$ nieco bardziej rozwiniętej u Buchanana tytulatury Boga oraz wizji gwiezdnego pałacu jako Jego rezydencji. Niewykluczone jednak, że sygnalizuje kontekst eklezjalny - wielbiący Boga mocarze i królowie skłonią się przed Nim „w kościele świętym”. Czy chodzi o świątynię? Współcześni wydawcy zgodnie transkrybują ten leksem minuskułą. Owa interpretacja mogłaby, swoją drogą, podążać po prostu za marginaliami Santego Pagniniego, który, charakteryzując cały psalm, pisze, że formułuje on zachętę do tego, by oddawać Bogu chwałę „in eius sanctuario”. Różnica między Buchananowymi wizjami gwiezdnego pałacu i „kościoła” jest wszakże bardziej znacząca i może zakorzeniać się w znanych poecie komentarzach do Księgi Psalmów. To u św. Augustyna znajdujemy interpretację wskazująca na serca ludu (a więc: zgromadzenia Kościoła) jako właściwy przybytek Boży ${ }^{42}$.

Stwierdzenie, że Kochanowski w Psałterzu Dawidowym czerpie z różnych źródeł, brzmi jak truizm, lecz istotne wydaje się podkreślenie jego egzegetycznej - i poetyckiej - samodzielności, gdyż to ona oddala jego dzieło od „psalmów metrycznych”, a wiedzie ku oryginalnej liryce psalmicznej. Progu tego jednak mistrz czarnoleski nie przekracza. Horacjańska psalmodia Buchanana, choć stale konsultowana i bez wątpienia określająca zasadniczy ton liryczny, pozostaje w napięciu z surowością dykcji biblijnej, mającej dla Kochanowskiego niezaprzeczalny powab. Kolejne wersety psalmiczne sa rusztowaniem dyskursu lirycznego we wszystkich utworach zbioru i poniekąd „zamykają” ich kompozycję. Lecz już u Sępa Szarzyńskiego dostrzec możemy, jak parafraza psalmu grawituje ku poezji traktującej wersety biblijne jedynie jako subtelny punkt odniesienia.

W zbiorze Rytmów abo wierszy polskich obok czterech (trzech dokładnych i jednego swobodnego) przekładów psalmów Buchanana (Pieśń I. Na psalm Dawidów XIX; Pieśń II. Na psalm Dawidów LII; Psalmu LVI Paraphrasis, Psalmu CXXX Paraphrasis) ${ }^{43}$, sa, jak wiadomo, dwie „pieśni na kształt psalmów” (Psalmu LXX i Psalmu CXXIII). W tych ostatnich nawiązania do tytułowych utworów biblijnych

Św. Augustyn, Objaśnienia psalmów: Ps 1-36. Przeł. J. Sulowski. Oprac. E. Stanula. Warszawa 1986, s. 216. Jeśli, idąc za sugestią B. S a n d e r s a (Ku nowej ocenie znaczenia źródet "Psatterza Dawidowego" Jana Kochanowskiego. Rola „In "Librum Psalmorum" Commentarius” Jana Kalwina. Przeł. E. B u s z e wi c z. „Terminus” 2000, z. 1/2), interpretować decyzję Kochanowskiego w kontekście dzieła In „Librum Psalmorum” commentarius Kalwina, okaże się, że wprawdzie stanowczo odrzucił on rozumienie tej przestrzeni chwały Bożej jako przybytków niebieskich (ku czemu wyraźnie skłaniał się Buchanan), lecz definiował ją jako Arkę Przymierza. Schrystianizowany obraz świątyni jerozolimskiej byłby właśnie „kościołem”.

43 M. Sęp Szarzyńs ki, Rytmy abo wiersze polskie. W: Poezje zebrane. Wyd. R. Grześ kowiak, A. Ka r pińs ki, przy współpr. K. M row c ewi z za. Warszawa 2001. Wszystkie fragmenty psalmów autorstwa tego poety cytuję z tej edycji. Wydawcy w Objaśnieniach (s. 155) piszą raczej o trzech przekładach psalmów Buchanana, traktując Sępową Psalmu CXXX Paraphrasis jako „luźno związaną" z odpowiednią parafrazą Szkota i wskazując na intertekstualną relacje polskiego wiersza z Psalmem 130 Kochanowskiego oraz z Psalmem 129 Seklucjana. Wcześniej J. A b r a m ow s ka - Kułtuniakow a (Psalmy Szarzyńskiego wobec psalmistyki renesansowej. „Zeszyty Naukowe Uniwersytetu Adama Mickiewicza. Filologia” 1958, nr 2, s. 58-61) także wykazała względnie 
służą jednak przede wszystkim identyfikacji sytuacji lirycznej, w której odnajduje się podmiot. Ich struktura tekstowa wprawdzie wciąż prześwieca w Sępowych wierszach, np.:

Ciebie, wszego stworzenia o Obrońco wieczny,

wzywam, $[\ldots]$

miej mię w pilnej opiece, [...]

pospiesz przynieść ratunek duszy mej [...].

(Pieśń na kształt Psalmu LXX, w. 1-4) ${ }^{44}$

[...] ciało zaślepione

[. . . . . . . . ]

Niech się wstyda, że pragnie duszy swej panować;

[. . . . . . . . . . . . . . . ]

I wy, wojska zazdrosne [...],

tył podajcie i weźmcie hańbę nieskończoną,

co dóbr, skąd was wygnano, stworzeniu Pańskiemu

nie życzycie $[\ldots]$.

(Pieśń na ksztatt Psalmu LXX, w. 5-7, 9-12) ${ }^{45}$

[...] oczy me płaczliwe

Tam podnoszę [...]

[...]

Jak słudzy od swych panów [...].

[.............. . . . . .

[...] by skromna od paniej panna, oczekiwa,

Rychło jej rękę podasz [...].

(Pieśń na ksztatt Psalmu CXXIII, w. 5-11) ${ }^{46}$

Następstwo wersetów biblijnych, które z grubsza organizują logikę monologu

swobodny związek Psalmu CXXX Paraphrasis z wersją Buchanana, podkreślając m.in. oddziaływanie Kochanowskiego i Seklucjana.

Por. $\mathrm{z}$ wersja S. Pa g n in i e go (op. cit., s. 248 〈Ps 70, 2〉): „Deus, ut ervas me, Iehovah, ad auxilium mei festina" [Boże, aby mnie wyrwać, Jahwe, pośpiesz mi na pomoc]". Por. też Ps 69,2 w wersji Wulgaty: „Deus, in adiutorium meum intende, Domine, ad adiuvandum me festina [Boże, zwróć się ku memu wspomożeniu, pośpiesz, aby mnie wesprzećl”. Cyt. z Wulgaty za edycją: Biblia sacra Vulgatae editionis [...] recognita et edita. Antverpiae 1605.

Por. S. Pa g n in i, op. cit., s. 248 (Ps 70, 3): „Pudore afficiantur, et erubescant quaerentes animam meam. Convertantur retrorsum, et erubescant volentes malum meum [Niech się okryją hańbą i zawstydzą szukający mojej duszy. Niech wstecz uciekają i zawstydzą się życzący mi zła]”. Por. też Ps 69, 3 w wersji Wulgaty: „Confundantur et revereantur, qui quaerunt animam meam. Avertantur retrorsum, et erubescant, qui volunt mihi mala [Niech się zmieszają i przestraszą, którzy szukają mej duszy. Niech się w tył zwrócą i zawstydzą, którzy życzą mi zła]”.

Por. S. Pa g n in i, op. cit., s. 451 (Ps 123, 1-2): „Ad te levo oculos meos, qui habitas in caelis. Ecce, sicut oculi servorum intenti sunt ad manum dominorum suorum, sicut oculi ancillae ad manum dominae suae, ita oculi nostri ad Iehovam Deum nostrum, donec misereatur nostri [Do Ciebie podnoszę me oczy, który mieszkasz w niebiosach. Oto, jak oczy sług są wpatrzone w rękę ich panów, jak oczy niewolnicy w rękę jej pani, tak oczy nasze w Jahwe Boga naszego, aż się zmiłuje nad nami]”. Por. też w wersji Wulgaty Ps 122, 1-2: „Ad te levavi oculos meos, qui habitas in caelis. Ecce sicut oculi servorum, in manibus dominorum suorum, sicut oculi ancillae in manibus dominae suae, ita oculi nostri ad Dominum Deum nostrum, donec misereatur nostri [Do Ciebie podniosłem oczy moje, który mieszkasz w niebiosach. Oto jak oczy sług w rękach ich panów, jak oczy niewolnicy w rękach jej pani, tak oczy nasze u Pana Boga naszego, aż się zmiłuje nad nami]”. 
lirycznego, bynajmniej jednak nie determinuje jego kompozycji, tak że zdaje się on otwierać również na inne źródła tekstowej inspiracji. Jak wykazali współcześni edytorzy i komentatorzy, w Pieśni na kształt Psalmu LXX nieprzyjaciele psalmisty przedstawieni zostali przez polskiego poetę $\mathrm{w}$ tak istotnej dla niego, a wywodzaccej się $\mathrm{z}$ literatury dewocyjnej popularnej triadzie: ciało, szatan, świat ${ }^{47}$. W jego osobistej interpretacji psalmów wspierają go też komentarze (na co nie zwrócono dotychczas uwagi), w każdym zaś razie tradycja Objaśnień psalmów św. Augustyna. W egzegezie biskupa Hippony także pojawia się m.in. szatan jako jeden z wrogów psalmisty, ale znacznie wyraźniejsze nawiązanie uwidocznia się w wierszach 13-16 utworu Sępa:

Szczęście me, Chwało moja, niech wskok wstyd poczują,

którzy mi inszą chwałę, nie Ciebie, cukrują.

Co ma człowiek nie Twego? A który sie chlubi

Z darów Twych, wieczny Królu, dary Twoje zgubi.

Z jednej strony, poeta niewątpliwie odnosi się tu do w. 4 Psalmu 69, który w wersji Wulgaty brzmi: „Avertantur statim erubescentes, qui dicunt mihi: "Euge, euge "[Niech się natychmiast zawstydzą, którzy mi mówią "Dobrze, dobrze «]", $z$ drugiej zaś, interpretuje go dokładnie w duchu św. Augustyna, który objaśniał, że słowa te stosują się do pochlebców groźniejszych niż zabójcy, i dodawał:

dlaczego bowiem mnie chwalą? Niechaj wielbią Boga. Czymże ja jestem, żeby mnie chwalić? Cóż bowiem wielkiego dokonałem? Cóż mam, czego bym nie otrzymał? ${ }^{48}$

Także w Pieśni na kształt Psalmu CXXIII rozwinięty obraz nieba (,Tobie Cheruby krzyczą: "Święty, święty, święty"! / Tobie Seraf, miłości prawej płomień czysty, / A twej chwały dwór znaczy firmament ognisty", w. 2-4) - który poeta jakby wyprowadzał z lapidarnego „qui habitas in caelis” (Ps 123, 1) - zdaje się mieć wiele wspólnego z Augustyńską interpretacją całego psalmu jako wyrazu tęsknoty za ojczyzną niebieską oraz z następującym fragmentem komentarza:

Niebem już są ci, w których Bóg już istotnie zamieszkuje, to jest w oglądających Go twarzą w twarz. Wszyscy święci aniołowie, wszystkie święte Moce, Potęgi, Stolice, Panowania, owe Jeruzalem niebieskie, do którego wzdychamy pielgrzymując, i do którego modlimy się, pragnąc go. Tam zamieszkuje Bóg ${ }^{49}$.

Zob. Objaśnienia, s. 157. - M. Kuran, Jak Mikołaj Sęp Szarzyński czytał psalmy. Analiza „V Pieśni na ksztatt Psalmu LXX”. „Acta Universitatis Lodziensis. Folia Litteraria Polonica” t. 12 (2009), s. 7-9.

48 Św. Augu sty n, Objaśnienia psalmów: Ps 58-77. Przeł. J. Sulowski. Oprac. E. Stanula. Warszawa 1986, s. 229. W tym kontekście jasne się staje także osobliwe użycie przez S ę p a przysłówka „dobrze” w wersie 18 w Pieśni na kształt Psalmu LXX: „To szczęśni, to weseli, którzy wyznawają, / Że Twe jest, co jest d obrze, i Ciebie szukają [...]" (w. 17-18). Słowa te wiążą się, co oczywiste, z pierwszą częścią kolejnego wersetu - 5, Ps 69: „Gaudeant et laetentur in te omnes quaerentes te [Niech się weselą i radują w Tobie wszyscy szukający Ciebie]", ale zarazem wciąż wybrzmiewa w nich ów aprobatywny wykrzyknik „Euge, euge!” z poprzedzającej frazy. Szczęśliwi, którzy szukają Boga, nie ulegają zachętom płynącym z ust pochlebców i wiedzą, że tylko o tym, co Boże, można powiedzieć „dobrze” - „od Niego bowiem pochodzi ich zbawienie, nie od nich”, dodaje św. Augu sty n (Objaśnienia psalmów: Ps 58-77, s. 231).

49 Św. Augu st y n, Objaśnienia psalmów: Ps. 103-123. Przeł. J. Sulow s ki. Oprac. E. St a nula. Warszawa 1986, s. 386. 
Wsparta lektura teologicznego komentarza medytacja psalmiczna rozsadza rygory parafrazy, a monolog Dawida wzbiera głosem chrześcijańskiego lektora-poety, który, interioryzując tekst biblijny, interpretuje go i poddaje indywidualizującej rekonstrukcji. Tak więc pojawiająca się na początku Pieśni na kształt Psalmu LXX sławna formuła: „wątły, ubogi i nigdzie bezpieczny” (w. 2), okaże się okruchem charakteryzującego kondycje psalmisty wersetu 6 z Psalmu 69 w wersji Wulgaty: „egenus, et pauper sum [A jam jest ubogi i żebrak]”, do którego przecież nawiązywać będzie także przedostatnia strofa utworu. Idea Boga, którego wzywa się jako wyzwoliciela i obrońce, uruchamia rycersko-militarne asocjacje obrazowe, te zaś skłaniają do wprowadzenia subtelnej reminiscencji horacjańskiej: „Ale kto jest szczęśliwy, choć dyjamentową / wdział zbroję, wojnę cierpiąc długą i surową?” (w. 25-26) ${ }^{50}$.

Fenomen poezji Sępa, wciąż tajemniczej, sytuuje się w przestrzeni zakreślonej, z jednej strony, przez oddziaływanie inspiracji horacjańskiej, dla której emblematyczne jest imię Buchanana, z drugiej zaś - jak sądzę - petrarkizmu duchownego, czego sygnałem pozostaje (na obecnym etapie badań) zespolenie formy sonetowej, awangardowej w literaturze polskiej, $z$ tematem religijnym czy też użycie kancony w Psalmu CXXX Paraphrasis ${ }^{51}$. Petrarkistowska liryka psalmiczna we Włoszech mierzyła się $z$ tym samym w istocie zadaniem, które stawiała sobie humanistyczna psalmodia horacjańska, a więc dążyła do restytucji ontologii poetyckiej psalmów biblijnych, naruszonej lub wręcz utraconej w kolejnych etapach językowej translacji, od Septuaginty poczawszy. Cel, który horacjaniści zasadniczo usiłowali osiągnąc w materii języka łacińskiego, przedstawiciele petrarkizmu duchownego pragnęli urzeczywistnić w poezji pisanej in volgare, co w oczywisty sposób skłaniało do imitacji „klasycznego” idiomu liryki wernakularnej utrwalonego w Canzoniere. Dlatego, jak pisze w swej znakomitej rozprawie Ester Pietroban, XVI-wieczne włoskie „parafrazy psalmiczne pozostają w dialektycznej relacji z architekstem Petrarkowskim" ${ }^{2}$. Jako że sama twórczość toskańskiego poety ma głębokie korzenie biblijne, a historia „il primo giovenile errore [pierwszego młodzieńczego błędu]” (Rerum vulgarium fragmenta 1, w. 3) samotnika $z$ Wokluzy to w istocie opowieść o nawróceniu religijnym, petrarchismo spirituale bynajmniej nie stanowi jakiejś stylistycznej aberracji i naruszenia decorum, ale jest raczej sięgnięciem samego sedna rodzimej (czyli toskańskiej) tradycji, by w niej szukać oparcia dla prób rekonstrukcji oryginalnej suavitas pieśni Dawidowych, której zaprzepaszczenie opłakiwał już Dante Alighieri w Biesiadzie (Convivio) ${ }^{53}$. Bogactwo gatunków lirycznych i związanych $\mathrm{z}$ nimi metrów staje się narzędziem tej eksploracji.

W objętych reformacją krajach Europy Północnej zarówno gatunki liryczne, jak i przyporzadkowane im style nie były pozbawione pewnych konotacji religijnych; 
„słodkie pieśni”, a sonety w szczególności - należały do grzesznej sfery spraw światowych, nieodpowiednich dla tematu duchownego. W cytowanej tu przedmowie Jakuba Lubelczyka: Ku każdemu krześcijańskiemu człowieku a bratu w Panu Krystusie, wybrzmiewa zastrzeżenie, iż opracowane przez niego wierszowane psalmy $\mathrm{w}$ żadnym wypadku nie mają nic wspólnego $\mathrm{z}$ „dwornościa”, $\mathrm{z}$ definicji przecież próżną. W Anglii w tym samym czasie Matthew Parker oferował swój metryczny psałterz jako remedium na lubieżne pieśni i sonety - pełne skarg na oporne kochanki ${ }^{54}$. Tymczasem włoski, a nawet szerzej - romański petrarkizm duchowny, czynił „słodkie” liryki wernakularne poetyckim ekwiwalentem pieśni Dawidowych, ale także (co nieuchronne) wpisywał ludzką miłość w porządek miłości Bożej i określał wektor duchowego postępu ${ }^{55}$. To jednak, co z perspektywy protestanckiej mogło się jawić jako ambiwalentne i pełne dwuznacznego napięcia (a więc np. znany Petrarca spirituale Girolama Malipiera), w odniesieniu do paradygmatu Petrarkowskiego było po prostu ukazaniem innego aspektu, przysłoniętego do tej pory przez dość powierzchowne praktyki manierystycznej poezji miłosnej.

W literaturze polskiej najlepszym urzeczywistnieniem założeń petrarchismo spirituale stały się Rymy duchowne Sebastiana Grabowieckiego. W takiej perspektywie scharakteryzował je przed laty Andrzej Litwornia, zwracając uwagę na rolę, jaką liryka samego Petrarki i włoskich petrarkistów (Bernarda Tassa i Gabriela Fiammy) odegrała wśród poetyckich źródeł bledzewskiego opata ${ }^{56}$. Blisko 20 lat później ten wybitny badacz polsko-włoskich związków literackich wskazywał na potrzebę bardziej wnikliwej analizy „aktywnych lektur i zarazem wzorów [...]” liryki Grabowieckiego, podkreślając jednocześnie jego nadzwyczaj dobre obeznanie z rozmaitymi rime spirituali wydawanymi w latach siedemdziesiątych XVI wieku w Wenecji (gdzie polski poeta spędził kilka miesięcy w 1578 roku) ${ }^{57}$. Ten ważny postulat nadal pozostaje niezrealizowany, ale współczesne studia nad twórczością Bernarda Tassa i Gabriela Fiammy rzucają obecnie nowe światło na tak od niej zależne Rymy duchowne i skłaniają m.in. do tego, by myśleć o nich w perspektywie petrarkistowskiej psalmodii ${ }^{58}$.

54 Zob. D. S e rj e a n t s o n, „The Book of Psalms” and the Early-Modern Sonnet. „Renaissance Studies” 2015, z. 4, s. 633.

55 Zob. J. Rieu, Le Langage pétrarquiste de la poésie spirituelle. Quelques recueils catholiques. „Studia Litteraria Universitatis Iagellonicae Cracoviensis” 2012, z. 2, s. 74.

56 A. Lit w or n ia, Sebastian Grabowiecki. Zarys monograficzny. Wrocław 1976, s. 109-111, 115-116. O roli Fiammy pisał jako pierwszy E. P o r ę b o w i c z (Sebastian Grabowiecki ijego wzory. W: Studia literackie. Przedm. M. B r a h m e r. Kraków 1951. Pierwodruk: „Ateneum” t. 2 〈1894〉). Zależności od liryki Tassa wyśledził F. Ś mi ej a (New Sources of Sebastian Grabowiecki's Poetry. „The Slavonic and East European Review" t. $32\langle 1953\rangle$, nr 78, s. 228-229).

57 A. Litwornia, rec.: „Wysoki umyst $w$ dolnych rzeczach zawikłany”. Antologia polskiej poezji metafizycznej epoki baroku. Od Mikołaja Sępa Szarzyńskiego do Stanisława Herakliusza Lubomirskiego. Oprac., wstęp K. M r o w c e w i c z. Warszawa 1993. „Pamiętnik Literacki” 1996, z. 1, s. 223. Potrzeba nowych studiów nad relacją Grabowiecki-Tasso wydaje się tym większa, iż w świetle współczesnych badań można już chyba wyjaśnić notoryczny problem rzekomego „kwietyzmu” autora Rymów duchownych (na ten temat zob. przede wszystkim Cz. Hern a s, Barok. Wyd. 4. Warszawa 1980, s. 37. - P. U rb ań s ki, Natura i łaska $w$ poezji polskiego baroku. Okres potrydencki. Studia o tekstach. Kielce 1996). Jak się okazuje, B. Tasso sympatyzował z duchowościa J. de Valdésa, co znalazło wyraz w jego Salmi. Analiza porównawcza powinna uwidocznić tryb 
W obu setnikach dziełka Grabowieckiego licznie tam reprezentowane parafrazy psalmiczne (36) nie są w żaden sposób wyróżnione ${ }^{59}$, funkcjonują na takich samych prawach, co właśnie przekłady włoskich liryków Tassa lub Fiammy. Te pierwsze jednak to przecież również Salmi, w twórczości Fiammy zaś skrupulatni badacze doszukali się 51 psalmów poetyckich, z czego 10 znajduje się w tłumaczonych przez polskiego poete Rymach duchownych (Rime spirituali, 1570) ${ }^{60}$. Salmi (1560) Tassa nie sa, co trzeba w tym kontekście silnie podkreślić, przekładami czy nawet parafrazami psalmów, lecz oryginalnymi lirykami inspirowanymi poezją Dawidowa, osnutymi wokół takiej bądź innej osi biblijnych wersetów, których materia podlega wszakże znaczącej rekonfiguracji. Pod względem metrycznym są to kancony-ody i tak też Tasso w przedmowie do Margherity de Valois nazywa swe utwory: „Ode sacre, o Salmi”, traktując wyrafinowaną strukturę metryczną jako nośnik „klasyczności” i zarazem oryginalnej meliczności ${ }^{61}$. To właśnie u Tassa (którego zresztą później naśladował Fiamma) Grabowiecki znalazł model oryginalnej liryki psalmicznej, będącej już nie przekładem, ale re-kreacją pieśni Dawidowej w materiale wernakularnym i w kontekście chrześcijańskim, swobodnej w nawiazaniach biblijnych oraz klasycznych, śmiałej w wymiarze metrycznym, inwencyjnym i obrazowym:

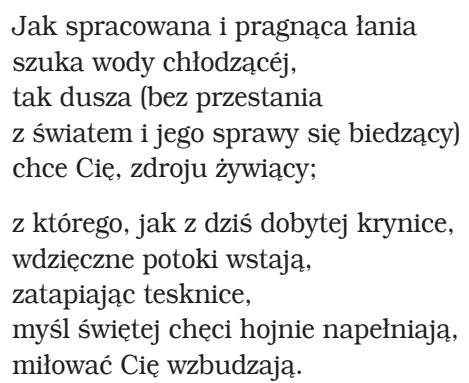

(Rymy duchowne II 54, w. 1-10) ${ }^{62}$

Kunsztowny przeplot 11- i 7-zgłoskowców naśladuje metryczny kształt kanco-

transmisji tych idei do poezji Grabowieckiego. Zob. R. M o r a c e, Bernardo Tasso e il gruppo valdesiano. Per una lettura „spirituale” dei „Salmi”. „Quaderno di italianistica” 2014.

Zob. M. H a n u s i e w i c z, Parafrazy psalmiczne Sebastiana Grabowieckiego. W zb.: Świt i zmierzch baroku. Red. M. Hanusiewicz, J. Dąbkowska, A. Karpiński. Lublin 2002.

Zob. Pi et r o b a n, op. cit., s. 58-59, 212. Pozostałe psalmy Fiammy znalazły się w zachowanych w rękopisie Bibl. Watykańskiej Parafrasi poetica sopra Salmi. Libro Primo (po r. 1562) oraz w Parafrasi poetica sopra alcuni Salmi di David Profeta (1571).

61 Zob. R. M or a c e, Del „rinovellare” la lingua volgare: i „Salmi” di Bernardo Tasso. W zb.: I cantieri dell'italianistica. Ricerca, didattica e organizzazione agli inizi del XXI secolo. A curo di B. Alf onzetti, G. Baldassarri, F. Tomasi. Roma 2014, s. 5-6. Na stronie: http://www.italianisti. it/upload/userfiles/files/2013_morace.pdf (data dostępu: 7 XI 2019).

62 Wszystkie cytaty z dzieła S. Grabowieckiego pochodza z edycji: Rymy duchowne. Wyd. K. Mrow cewicz. Warszawa 1996. BPS 5. W kilku miejscach wprowadzam drobne korekty na podstawie skolacjonowania edycji z pierwodrukiem: S. Grab owi e cki, Rymy duchowne, Kraków 1590. Zob. B. Ta s s o, Salmo XVII. W: Rime [...] divise in cinque libri nuovamente stampate. Libro quinto: Salmi. Vinegia 1560, k. 20r.: „Come assetata cerva ogn'hor desia / Fresca fontana, o rivo; / Cosi l'anima mia il mondo, e i suoi diletti havendo a schivo, / Te fonte eterno, e vivo: / Onde, si come da vena surgente / Si deriva un licore / Che ebbra rende la mente: / E la riempie d'un santo furore / Del tuo divino amore". 
ny, a oczywiste nawiązanie do Psalmu 42 (41) (w. 2) jest tu jedynie punktem wyjścia do żarliwego i całkowicie oryginalnego monologu tęsknoty za Bogiem, którego u kresu „nowy Dawid” pragnie oglądać twarzą w twarz. Ten sam okruch psalmicznego wersetu Grabowiecki uczyni zalążkiem całkowicie już (jak się wydaje) samodzielnego utworu, który zreszta umieszcza w swym zbiorze na poprzedniej karcie. W skierowanym do Chrystusa, ,źrzódła żywego” (w. 6), wierszu 51 z Setnika wtórego (inc. „Dobry Jezu, o moja ucieczko prawdziwa”) podmiot zwraca się do Boskiego adresata tymiż słowami psalmu: „Jak jeleń spracowany chłodnej szuka wody [...]" (w. 5), by w kolejnych strofach wprowadzić jednak nie mniej oczywiste nawiązania ewangeliczne (.,Jam jest owca błędliwa, Pasterzu łaskawy, / szukaj jej [...]”, w. 13-14) i zamknąć utwór wyraźnymi reminiscencjami z Psalmu 51 (52): „odmień płacz mnie w wesele [...]” (w. 15), „Nie patrz na mą niegodność [...]” (w. 17). Wzorem Włochów polski poeta pisze własną psalmodię i na równych prawach umieszcza $\mathrm{w}$ niej oryginalne teksty liryczne: przewierszowane modlitwy brewiarzowe oraz eucharystyczne, spolszczenia petrarkistowskich rime spirituali, wreszcie regularne parafrazy pieśni Dawidowych i innych kantyków biblijnych. Nawet wówczas jednak, gdy „po prostu” parafrazuje biblijny psalm, przekształca sytuację liryczną tak, by tekst stawał się bardziej otwarty na aktualizację i uniwersalizację.

Tak więc np. wiersz 47 z Setnika pierwszego, który już samym incipitem „Boże mój, o Boże mój, przeczżeś mnie porzucił" odsyła w sposób oczywisty do Psalmu 22 (21) i znamiennie modyfikuje tekst biblijny. Spośród 32 wersetów starotestamentalnego psalmu Grabowiecki wykorzysta tylko pierwszych 16, kształtując tak oto przejmującą, ale właśnie uniwersalną w wymowie skargę człowieka doświadczającego dramatycznego opuszczenia przez Boga i ludzi. Parafraza urwie się tam, gdzie w tekście biblijnym następuje niezwykle wyrazisty fragment o silnym wydźwięku mesjańskim, w komentarzach chrześcijańskich jednoznacznie odnoszony do Chrystusa. Obraz torturowanego skazańca, którego szaty dzielą między siebie jego prześladowcy i los rzucaja o jego suknię, byłby zbyt konkretny, żeby mieć potencjał aktualizacji w doświadczeniu każdego pobożnego lektora. Psalm biblijny zostanie więc „zawłaszczony” na potrzeby liryki indywidualnej tylko w pewnym zakresie i zamknięty dość konwencjonalnym wezwaniem, którego z parafrazą nic już nie łączy:

Nawróć swe oczy ku mnie, ojcowskiej miłości wzrusz, strzegąc od zginienia dusze i krewkości. [w. 31-32]

Grabowiecki był bodaj pierwszym polskim poetą, który w sposób - jak sądze zupełnie świadomy i konsekwentny podją próbę stworzenia kolekcji oryginalnej liryki psalmicznej ${ }^{63}$. Nie tomu parafraz metrycznych, ale tekstów będących re-kreacją psalmu jako poezji melicznej i zarazem chrześcijańskiej (co wybrzmiewa w jego dziełku nadzwyczaj mocno). Wzorem włoskich liryków Grabowiecki podkreślał poetycki i meliczny charakter swych „psalmów” za pomoca zróżnicowania gatunkowego i metrycznego. W Rymach znajdujemy 49 rodzajów strof i układów stroficznych, m.in. sonety, oktawy, tercyny, kancony, zwrotkę hejnałowa ${ }^{64}$. Jest w tej

63 Zob. Urbańs ki, op. cit., s. 86-88.

64 Zob. M. Hanusi ewi cz, Świat podzielony. O poezji Sebastiana Grabowieckiego. Rzym-Lublin 1994 , s. $128-156$. 
wirtuozerii pewna mechaniczność; Grabowieckiego ode sacre często dziwnie trącą prozą, bo też nieraz wywodzą się z modlitewnikowej prozy, a metryczny ornatus nie zawsze wystarcza, by przemienić je w poezję. Intencja wydaje się jednak wyraźna te „ozdobne” wiersze są nowym psałterzem, chrześcijańską i niewątpliwie „dworną” Sefer Tehilim, re-kreowaną w przyrodzonej mowie w sposób, który nie powinien budzić wątpliwości co do ich pieśniowego charakteru.

\section{5}

W wieku XVII model „nowego” psalmu - liryka psalmiczna - miał zostać podjęty przez licznych poetów. W tej perspektywie należy widzieć ewolucję gatunku elegii pokutnej, który jest w istocie wernakularną interpretacją psalmu penitencyjnego, a uprawiany był przez Kaspra Miaskowskiego, Olbrychta Karmanowskiego, Hieronima, Jana Andrzeja, Stanisława i Zbigniewa Morsztynów, Wespazjana Kochowskiego, Wacława Potockiego, Stanisława Herakliusza Lubomirskiego, Wojciecha Stanisława Chrościńskiego i innych ${ }^{65}$. Jeśli psalmy-hymny i psalmy-ody trafiły w poezji staropolskiej na mniej podatny grunt (bodaj do czasu oświecenia), to elegia pokutna kwitła, czemu sprzyjały być może lakrymalne nurty barokowej pobożności. Najwybitniejszym osiagnięciem staropolskiej liryki psalmicznej stanie się jednak Psalmodia polska Kochowskiego z jej dominującym tonem hymnicznym. W kolejnych stuleciach ten typ poezji, rozumiany jako rekonfiguracja, re-kreacja i medytacyjno-liryczna aktualizacja pieśni Dawidowej, podjetty został przez wielkich twórców romantycznych. Jest swoistym paradoksem, że $z$ niego właśnie wyrastają także współczesne wersje „psalmów świeckich”, w których liryczna i egzystencjalna „anatomia duszy” okazuje się nie tylko materia główną, ale też - jedyną. W przeważającym wszakże stopniu „psalmiczność” nadal stanowi poetycki wyznacznik przynajmniej określonej aksjologii 66 .

„Psalm nowy” stał się formą tyleż elastyczną, ile nieostrą, pozbawioną cech wyrazistych. I właśnie w tym wymiarze - nawet w swoich renesansowych i barokowych realizacjach - okazuje się strukturą bardzo nowoczesną. Wedle często cytowanej formuły Maurice'a Blanchota $\mathrm{z}$ jego pracy Le Livre à venir gatunki już przecież wyblakły, została jedynie literatura, potwierdzająca samą siebie, promieniejąca w tajemniczej jasności ${ }^{67}$.

Na temat staropolskiej elegii pokutnej zob. R. Grześ k ow i a k, Hieronim i Bóg. Z dziejów XVII-wiecznej elegii pokutnej. W zb.: Religijność literatury polskiego baroku. Red. Cz. H e r n a s, M. Hanu s i e w i c z. Lublin 1995. - J. Głaż e w s ki: Łzy, inkaust i skrucha. Słowo o XVII-wiecznej elegii pokutnej. W zb.: Śmiech i łzy $w$ kulturze staropolskiej. Red. A. Kar pińs ki, E. Las ocińs ka, M. H a n u s i e w i c z. Warszawa 2003; „Szczyrze się kajacemu grzech jest odpuszczony”. O poetyckim rachunku sumienia. „Barok” 2004, nr 2. W kontekście relacji elegii pokutnej do psalmu zob. zwłaszcza uwagi R. Grześk owiaka przedstawione we Wprowadzeniu do lektury w edycji Wierszy różnych O. Ka r m a n ow s k i e go (Warszawa 2010, s. 17-23).

66 Zob. A. Le ge ży ń s k a, Jeśli nie klasycyzm, to co? Próba rozpoznania jednej z odmian świadomości poetyckiej po 1989 roku. W zb.: Nowa poezja polska. Twórcy, tematy, motywy. Red. T. C i eśla k, K. Pietrych. Kraków 2009, s. 57-58.

67 Zob. J. Culle r, Theory of the Lyric. Cambridge, Mass. - London 2015, s. 40-41. 


\section{Abstract \\ MIROSŁAWA HANUSIEWICZ-LAVALLEE John Paul II Catholic University of Lublin ORCID: 0000-0001-8965-0023 \\ REMARKS ON THE POLISH PSALM LYRIC POETRY OF THE SECOND HALF OF THE $16^{\mathrm{TH}}$ CENTURY}

The article provides a reflection about the shaping of original psalm lyric poetry in the Polish Renaissance poetry of the second half of the $16^{\text {th }}$ century. The author shows its distinctness in contrast to the phenomenon of metrical psalms that served religious instructions, mnemonics, strengthening the congregation unity, all characteristic to Protestant authors. Psalm lyric poetry, in the understanding suggested here, is not a translation of psalm, but rather transcoding and updating its model in the idiom of mother tradition. Also, it refers to this model on the various levels of intertextual relations. The psalmic word in the poetry in question is subject to reconfiguration in order to become a building material of an original lyrical monologue being either individualised or adapted to a given situation (e.g. historical or private), though neither composition nor the content of Old Testament Psalm determines the structure of the piece. Growing, in part, from the experience of the paraphrase, psalm lyric poetry is not identical with it, and the factors stimulating its shaping in Old Polish poetry are Horatianism (Jan Kochanowski's and Mikołaj Sęp Szarzyński's oeuvre) as well as spiritual Petrarchism (Sebastian Grabowiecki's lyric poetry). 